Anahtar Sözcükler: Disentrik (7;12), Karışık-fenotip akut lösemi, Floresan in situ hibridizasyon, ETV6/RUNX1

Informed Consent: Informed consent was obtained from the patient.

\section{Authorship Contributions}

Concept: S.G.; Data Collection or Processing: S.G., N.S.; Analysis or Interpretation: A.R.G, M.B.; Writing: S.G.

Conflict of Interest: No conflict of interest was declared by the authors.

Financial Disclosure: The authors declared that this study received no financial support.

\section{References}

1. Borowitz MJ, Bene MC, Harris NL, Porwit A, Matutes E, Arber DA. Acute

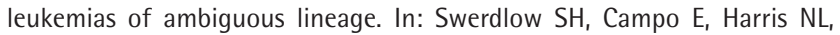
Jaffe ES, Pileri SA, Stein H, Thiele J (eds). WHO Classification of Tumours of Haematopoietic and Lymphoid Tissues, Revised 4th Edition, Volume 2. Lyon, IARC Press, 2017.

2. Matsumoto $Y$, Taki T, Fujimoto $Y$, Taniguchi $K$, Shimizu D, Shimura $K$, Uchiyama H, Kuroda J, Nomura K, Inaba T, Shimazaki C, Horiike S, Taniwaki M. Monosomies $7 p$ and $12 p$ and FLT3 internal tandem duplication: possible markers for diagnosis of $\mathrm{T} /$ myeloid biphenotypic acute leukemia and its clonal evolution. Int J Hematol 2009;89:352-358.

3. Rubio MT, Dhedin N, Boucheix C, Bourhis JH, Reman O, Boiron JM, Gallo $J H$, Lhéritier V, Thomas $X$, Fière $D$, Vernant JP. Adult T-biphenotypic acute leukaemia: clinical and biological features and outcome. $\mathrm{Br} J$ Haematol 2003;123:842-849.

4. Tiribelli M, Damiani D, Masolini P, Candoni A, Calistri E, Fanin R. Biological and clinical features of T-biphenotypic acute leukaemia: report from a single centre. Br J Haematol 2004;125:814-815.

5. Owaidah TM, Al Beihany A, Iqbal MA, Elkum N, Roberts GT. Cytogenetics, molecular and ultrastructural characteristics of biphenotypic acute leukemia identified by the EGIL scoring system. Leukemia 2006;20:620-626.

6. MacKinnon RN, Campbell $\amalg$. The role of dicentric chromosome formation and secondary centromere deletion in the evolution of myeloid malignancy. Genet Res Int 2011;2011:643628.

7. Raimondi SC, Privitera E, Williams DL, Look AT, Behm F, Rivera GK, Crist WM, Pui CH. New recurring chromosomal translocations in childhood acute lymphoblastic leukemia. Blood 1991;77:2016-2022.

8. Pan J, Xue $Y$, Wu Y, Wang $Y$, Shen J. Dicentric $(7 ; 9)(p 11 ; p 11)$ is a rare but recurrent abnormality in acute lymphoblastic leukemia: a study of 7 cases. Cancer Genet Cytogenet 2006;169:159-163.

9. Wafa A, Jarjour RA, Aljapawe A, ALmedania S, Liehr T, Melo JB, Carreira IM, Othman MAK, Al-Achkar W. An acquired stable variant of a dicentric dic $(9 ; 20)$ and complex karyotype in a Syrian childhood B-acute lymphoblastic leukemia case. Mol Cytogenet 2020;13:29.

10. Illade L, Fioravantti V, Andion M, Hernandez-Marques C, Madero L, Lassaletta A. Dicentric translocation $(9 ; 12)$ in acute lymphoblastic leukemia: a chromosomal abnormality with an excellent prognosis? Tumori 2017;103(Suppl 1):e44-e46.

11. Tapinassi C, Gerbino E, Malazzi O, Micucci C, Gasparini P, Najera MJ, Calasanz MJ, Odero MD, Pelicci PG, Belloni E. A new dic(7;12)(p12.21;p12.2) chromosome aberration in a case of acute myeloid leukemia. Cancer Genet Cytogenet 2008;185:102-105.

\title{
A Novel Variant in the ACVRL1 Gene in a Patient with Cirrhosis and Hereditary Hemorrhagic Telangiectasia
}

\author{
Herediter Hemorajik Telenjiektazi ve Sirozu Olan bir Hastada ACVRL1 Geninde Saptanan Yeni \\ Bir Varyant
}

(1) Mehmet Baysal1', (1) Nihan Alkış ${ }^{1}$, (1) Hakan Gürkan22, (1) Ahmet Muzaffer Demir³

${ }^{1}$ Bursa City Hospital, Clinic of Hematology, Bursa, Turkey

2Trakya University Faculty of Medicine, Department of Medical Genetics, Edirne, Turkey

${ }^{3}$ Trakya University Faculty of Medicine, Department of Hematology, Edirne, Turkey

\section{To the Editor,}

Hereditary hemorrhagic telangiectasia (HHT) is a rare bleeding disorder characterized by arteriovenous malformations (AVMs), telangiectasia, and bleeding episodes [1]. Pulmonary, hepatic, and cerebral AVMs may be seen in the course of the disease [2]. Mutations in the ENG, ACVRL1, and SMAD4 genes were associated with HHT [3]. A 65-year-old man was admitted to our hospital with anemia and intermittent nose bleeding. 
Upon physical examination, telangiectasias were noticed on his face and nose. Further investigations in his work-up revealed hypochromic microcytic anemia with a hemoglobin level of $8 \mathrm{~g} / \mathrm{dL}$. Detailed laboratory analysis revealed iron deficiency anemia. In the upper gastrointestinal endoscopy performed for iron deficiency anemia, grade 1 esophageal varices were detected and intravenous iron carboxymaltose treatment was planned. His epistaxis severity score was 3.22 , which can be categorized as mild bleeding [4].

Family history revealed positive findings for nose bleeds and telangiectasia in his first-degree relatives and molecular genetic analysis was performed on a next-generation sequence analysis platform (NextSeq550-Illumina) using the QIAseq Targeted DNA Panel Kit (CDHS-14647Z-252-QIAGEN), which includes the ACVRL1, ADAM17, ENG, GDF2, PTPN14, RASA1, and $S M A D 4$ genes. Variant analysis was performed using OIAGEN Clinical Insight software. As a result of the bioinformatics analysis performed considering the ACMG-2015 criteria, the NM_000020.3(ACVRL1):c.1415G>A (p.Trp472Ter) variant was evaluated as pathogenic according to the PVS1, PM2, and PP3 rules (in silico analysis results - DANN score: 0.9944, GERP score: 4.4, MutationTaster: Disease causing). The ACVRL1:c.1415G>A variant was reported in the dbSNP database with reference number rs1555154144, but its clinical significance was not reported in the ClinVar or HGMD Professional 2020.3 databases. The minor allele frequency was not reported in the dbSNP, ExAC, or GnomAD_exome databases $[5,6]$. Computed tomography of the abdomen showed nodularity of the surface of the liver, a heterogeneous appearance of the liver parenchyma, and atrophy of the left liver lobe (Figure 1). No arteriovenous malformations were found in the liver and evaluation of the portal venous system was normal. Hepatitis virus markers, immunoglobulin levels, and autoimmune markers were normal. As the patient's anamnesis was detailed, a history of regular alcohol consumption was noted and the patient was diagnosed with Child A liver parenchymal disease. A colonoscopic evaluation of the patient was also performed, and multiple small telangiectases were seen in the rectal mucosa. Local preventive measures and tranexamic acid were given for epistaxis and low-dose propranolol was started for grade 1 esophageal varices.

Gastric and hepatic manifestations of HHT are broad, and on rare occasions HHT can be associated with liver cirrhosis $[7,8]$. However, as in our case, HHT and alcohol intake have both caused and triggered liver cirrhosis. Our patient has stopped consuming alcohol and is being followed as an outpatient for both HHT and cirrhosis. Mutations in the ACVRL1 gene occur more frequently in HHT type 2 patients, and according to the University of Utah mutation database there are 571 confirmed variants in the ACVRL1 gene associated with HHT; our novel variation was not reported before [9]. Regardless of the age of the patient, HHT should be on the physician's mind when

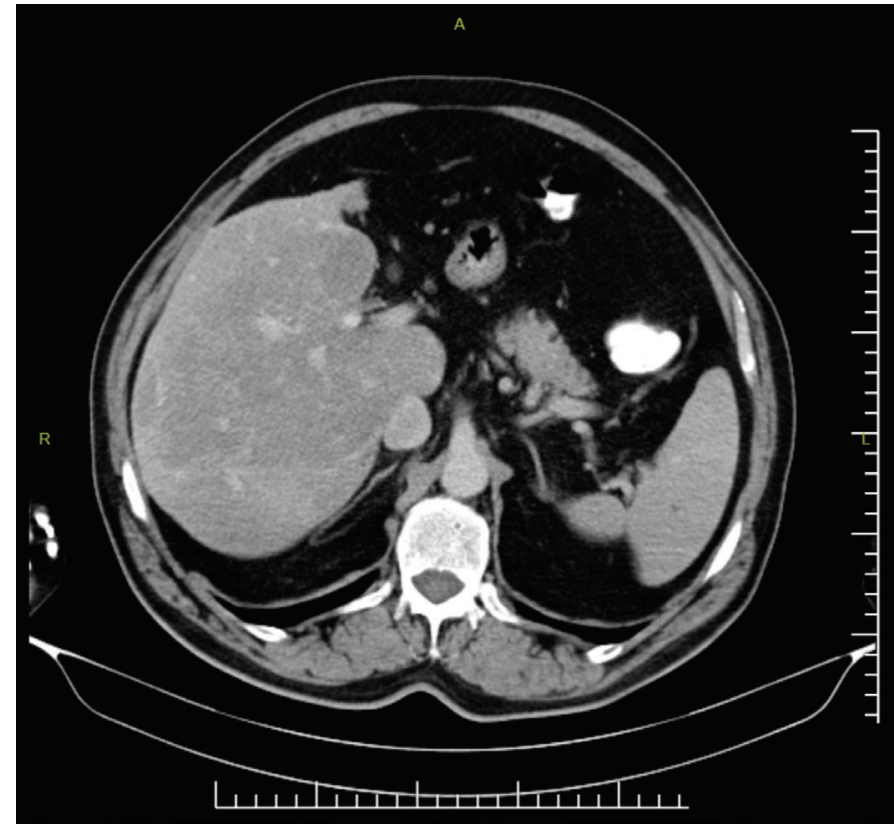

Figure 1. Computed tomography of the abdomen showed nodularity of the surface of the liver, a heterogeneous appearance of the liver parenchyma, and atrophy of the left liver lobe.

evaluating a patient with telangiectasias and unexplained iron deficiency.

Keywords: Hereditary hemorrhagic telangiectasia, ACVRL1 mutation, Cirrhosis, Epistaxis, Anemia

Anahtar Sözcükler: Herediter hemorajik telenjiektazi, ACVRL1 mutasyonu, Siroz, Epistaksis, Anemi

Informed Consent: Informed consent has been obtained from the patient.

\section{Authorship Contributions}

Concept: M.B., N.A., H.G., A.M.D.; Design: M.B., N.A., H.G., A.M.D.; Data Collection or Processing: M.B., N.A., H.G., A.M.D.; Analysis or Interpretation: M.B., N.A., H.G., A.M.D.; Literature Search: M.B., N.A., H.G., A.M.D.; Writing: M.B., N.A., H.G., A.M.D.

Conflict of Interest: No conflict of interest was declared by the authors.

Financial Disclosure: The authors declared that this study received no financial support.

\section{References}

1. Shovlin CL, Guttmacher AE, Buscarini E, Faughnan ME, Hyland $R H$, Westermann CJ, Kjeldsen AD, Plauchu H. Diagnostic criteria for hereditary hemorrhagic telangiectasia (Rendu-Osler-Weber syndrome). Am J Med Genet 2000;91:66-67.

2. Faughnan ME, Mager JJ, Hetts SW, Palda VA, Lang-Robertson $K$, Buscarini E, Deslandres E, Kasthuri RS, Lausman A, Poetker D, Ratjen F, Chesnutt MS, Clancy M, Whitehead KJ, Al-Samkari H, Chakinala M, Conrad M, 
Cortes D, Crocione C, Darling J, de Gussem E, Derksen C, Dupuis-Girod S, Foy P, Geisthoff U, Gossage JR, Hammill A, Heimdal K, Henderson K, lyer VN, Kjeldsen AD, Komiyama M, Korenblatt K, McDonald J, McMahon J, McWilliams J, Meek ME, Mei-Zahav M, Olitsky S, Palmer S, Pantalone R, Piccirillo JF, Plahn B, Porteous MEM, Post MC, Radovanovic I, Rochon PJ, Rodriguez-Lopez J, Sabba C, Serra M, Shovlin C, Sprecher D, White AJ, Winship I, Zarrabeitia R. Second international guidelines for the diagnosis and management of hereditary hemorrhagic telangiectasia. Ann Intern Med 2020;173:989-1001.

3. Baysal M, Demir S, Ümit EG, Gurkan H, Bas V, Karaman Gülsaran S, Demirci U, Kirkizlar HO, Demir AM. Genetic diagnosis of hereditary hemorrhagic telangiectasia: four novel pathogenic variations in Turkish patients. Balkan Med J 2020;37:43-46.

4. Hoag JB, Terry P, Mitchell S, Reh D, Merlo CA. An epistaxis severity score for hereditary hemorrhagic telangiectasia. Laryngoscope 2010;120:838-843.

5. Bossler AD, Richards J, George C, Godmilow L, Ganguly A. Novel mutations in ENG and ACVRL1 identified in a series of 200 individuals undergoing clinical genetic testing for hereditary hemorrhagic telangiectasia (HHT): correlation of genotype with phenotype. Human Mutation 2006;27:667675.

6. Richards S, Aziz N, Bale S, Bick D, Das S, Gastier-Foster J, Grody WW, Hegde M, Lyon E, Spector E, Voelkerding K, Rehm HL; ACMG Laboratory Quality Assurance Committee. Standards and guidelines for the interpretation of sequence variants: a joint consensus recommendation of the American College of Medical Genetics and Genomics and the Association for Molecular Pathology. Genet Med 2015;17:405-424.

7. $\mathrm{Xu} B G$, Liang J, Jia $K F$, Han T. Liver cirrhosis in a patient with hepatic hereditary hemorrhagic telangiectasia and Budd-Chiari syndrome: a case report. BMC Gastroenterol 2020;20:169.

8. Tortora A, Riccioni ME, Gaetani E, Ojetti V, Holleran G, Gasbarrini A. RenduOsler-Weber disease: a gastroenterologist's perspective. Orphanet J Rare Dis 2019;14:130.

9. University of Utah. Hereditary Hemorrhagic Telangiectasia Mutation Database. Salt Lake City, University of Utah Department of Pathology, 2020. Available at http://www.arup.utah.edu/database/HHT.

\title{
Can Hematological Findings of COVID-19 in Pediatric Patients Guide Physicians Regarding Clinical Severity?
}

\author{
Pediatrik Hastalarda COVID-19 Hematolojik Bulguları Klinisyenlere Klinik Ciddiyet Açısından \\ Yol Gösterebilir mi?
}

\author{
(1) Kamile Ötiken Arıkan, (DS Şahika Şahinkaya, (1) Elif Böncüoğlu, (D) Elif Kıymet, (1) Ela Cem, (1) Aybüke Akaslan Kara, (D) Nuri Bayram, \\ (1) ilker Devrim
}

University of Health Sciences Turkey, Izmir Dr. Behçet Uz Children Hospital, Clinic of Pediatric Infectious Disease, Izmir, Turkey

\section{To the Editor,}

The coronavirus disease-19 (COVID-19) pandemic originated in December 2019 in the city of Wuhan, the capital of Hubei Province, China. The virus then spread to numerous other countries in Asia and by January 2020 infected patients were identified in Europe [1]. Children of all ages are susceptible to infection by severe acute respiratory syndrome-coronavirus-2, the causative agent. Most children have relatively mild clinical symptoms without fever or pneumonia $[2,3,4,5,6,7,8]$.

We conducted a retrospective study at the University of Health Sciences Turkey, İzmir Dr. Behçet Uz Children's Hospital between March 30 and October 31, 2020.

A total of 3878 pediatric patients were tested and 353 (9.1\%) of them were diagnosed with COVID-19. Of these 353 children, 184 (52.1\%) were male (52.1\%) (female/male: 0.91).
The median age of the patients was 9 years (range: 4 days to 17 years). Thirty-five (9.9\%) patients had underlying diseases, most commonly a neurological disease $(n=9)$. Regarding severity, 9 (2.5\%), 293 (83\%), 38 (10.8\%), and 13 (3.7\%) cases were diagnosed as asymptomatic, mild, moderate, and severe/critical, respectively. Neutropenia (47.9\%) was the most common abnormal parameter in complete blood counts, followed by lymphocytosis (22.4\%), lymphopenia (20.7\%), leukopenia (9.1\%), neutrophilia (6.5\%), and thrombocytopenia (3.4\%) (Table 1).

Neutropenia was statistically significantly more common in neonates (84.6\%). Lymphocytosis and neutrophilia were statistically significantly more common in infants (75.9\%, $p<0.001$ and $23.3 \%, p<0.001$, respectively). Lymphopenia and leukopenia were statistically significantly more common in patients $>11$ years old $(38.4 \%, p<0.001$ and $15.2 \%, p=0.025$, 